\title{
Browntop Millet- A Review
}

\author{
Sujata Bhat*, Prabhu C Ganiger , Nandini C, Prabhakar and Thippeswamy V \\ Project Coordinating Unit, University of Agricultural Sciences, India
}

Submission: February 02, 2018; Published: March 29, 2018

"Corresponding author: Sujata Bhat, Technical Assistant, (Research), Project Coordinating Unit, AICRP on Small millets, University of Agricultural Sciences, GKVK, Bengaluru-560065, India, Email: sbsujiraghu@gmail.com

Abstract

Browntop millet is a warm season annual grass that is a heavy seed producer. This millet seed is grown in a variety of soils and climates. Browntop millet is used as a wild life food plot crop, livestock summer grazing crop, for erosion control, hay production and as a food grain crop. Under ideal conditions seed will germinate within five days and forage or seed will be ready to harvest within two months time. Browntop millet is an effective nurse crop, much like oats, in stabilizing erosive hill slopes and providing cover for slower growing target species to become established. With the ability to easily reseed and that seed to remain viable in the soil profile for years, makes browntop millet an excellent regenerating food plot for wild life.

Keywords: Browntop millet; Cover crop; Wild life; Forage

\section{Introduction}

Browntop millet (Brachiaria ramosa (L.) Stapf; Panicum ramosum L.) is an introduced annual grass that originated in South-East Asia. It is grown in Africa, Arabia, China and Australia [1]. It was introduced to the United States from India in 1915 [2]. In the US, it is mainly grown in the South-East for hay, pasture and game bird feed. The browntop millet, called korale in Kannada, is specially grown in rainfed tracts of Tumakuru, Chitradurga and Chikkaballapura districts of Karnataka state. The crop is popular in this region in terms of cultivation and consumption. This millet seed is grown in a variety of soils and climates. Like other millets, it is a hardy crop and well suited for dry land.

\section{Description}

Browntop millet is an annual warm-season species that grows 1 to $3 \mathrm{ft}$ tall. The smooth stems have pubescent nodes and may stand erect or ascend from a decumbent base. The leaves are 2.2 to $18 \mathrm{~cm}$ long and $6-18 \mathrm{~mm}$ wide; both surfaces are smooth. The inflorescence is indeterminate, open, spreading with simple axis and stalked flowers. It has 3-15 inflorescences and white flowers. Seeds are ellipsoid and tan in colour; they mature in approximately 60 days [3].

\section{Uses}

Forage/grain: Compared to other warm season forage grasses, browntop millet is relatively low yielding. Its strength is that it is a rapidly maturing grass, often used as a catch crop, cover crop or nurse crop [4]. Browntop millet can accumulate toxic/lethal levels of nitrate and should not be fed to livestock if the plant has been stressed by droughty or cold conditions. There is evidence of the cultivation of browntop millet as a subsistence crop in Neolithic India and it continues to be used as a grain and forage crop in India today [5]. Grains from taller nonshattering varieties are used as a boiled whole grain, porridge or unleavened bread [6].

a. Cover crop: Browntop millet is used to suppress rootknot nematode populations in tomato and pepper crops in the South-East [7]. It is grown as a fast-growing catch crop between commodity crops and is not known to be allelopathic.

b. Critical area planting: Browntop millet is used as a fast growing cover for erosion control. It is used as a nurse crop in the South-East until a perennial grass cover is established. It also has the ability to accumulate significant amounts of lead and zinc in shoot and root tissues making it an important plant for remediation of contaminated soils [8].

c. Wild life: Browntop millet produces large quantities of seeds. These millet seeds are used in food plots for game birds that are highly attracted to the nutritious seed. Browntop millet is one of the few types of millet that can be planted and flooded for ducks or planted in dry areas for deer, quail, dove, turkey and other wild life. 


\section{Cultivation}

Planting time: Browntop millet can be planted from midApril until mid August in most locations, though later plantings will result in lower yields.

Seed rate and planting: The seed rate for browntop millet will depend upon both the target species (birds \& wild life) and the seedling method. Birds food plots are generally seeded at the rate of approximately $4-5 \mathrm{~kg}$ per acre when planted in rows and $11-12 \mathrm{~kg}$ per acre when broadcast. Seed should be covered to a depth of half inches in a firm seed bed [9]. Browntop millet can be used in combination with a variety of agricultural crops or other species planted for wild life. The species commonly planted intercropping with browntop are sunflowers, corn, sorghum, soybean, and peas. This method is ideally suited to larger fields, in which the millet is planted in alternating strips with other crops.

In Karnataka state, farmers popularly/locally called browntop millet as branched or chaduru korale and Round panicle/Dundu korale. Normally branched one has low pests and diseases, where as round panicle browntop millet give higher yields. They use the traditional drillers for sowing the seeds one inch below the top soil. This method is recommended for a better yield. Five kg seeds are required per acre. Seeds get germinate by the fifth day of sowing. Farmers get seven to eight quintal grains per acre and four tractor loads of good quality fodder. They consume grains by making roti or as rice. The crop matures within 60-70 days. The shelf life of seed is about five to six years, while the shelf life of browntop rice is only about 25 to 30 days [10].

\section{Fertilizer}

Fertilization with phosphorous and nitrogen can help increase forage productivity; rate of application should be determined by the results of soil tests and /or country recommendations.

Weed management: To control weeds, it is best to plant in a well-tillaged field, weed-free bed with narrow row spacing. Chemical weed control options are limited. It does not regrow well after cutting, so it is a one -cut crop.
Seed processing: The cultivation of browntop is simple but processing is difficult due to the hard outer cover of the seed. As a result, farmers get only $40-50 \mathrm{~kg}$ of rice from one quintal of browntop/korale seeds. Earlier grinding stones were used to separate the grain from the seed. Today, grinding stones have almost disappeared and korale seeds are processed in the flour mills that process finger millet [10]. The size of korale rice is also very small and separation of stones is difficult. Hence, processing has become a bottleneck for farmers, and efforts are on to design improved processing machines.

\section{References}

1. Clayton WD, Vorontsova MS, Harman KT, Williamson H (2006) Grass Base-the online world grass flora.

2. Oelke EA, Oplinger ES, Putnam DH, Durgan, BR, Doll JD, et al. (1990) Millets. In: Alternative Field Crops Manual. Univ of Wisc-Ext Serv, Univ of Minn ExtServ and Univ.of Minn. CAPAP.

3. Sheahan CM (2014) Plant guide for browntop millet (Urochloa ramosa). USDA-Natural Resources Conservation Service, Cape May Plant Materials Center, Cape May.

4. Miller P, Lord E (2007) Florida cow-calf management. ( $2^{\text {nd }}$ edn), Forages Univ of FL, UF/IFAS Extension.

5. Madella M, Lancelotti C, Garcia-Granero JJ (2013) Millet microremainsan alternative approach to understand cultivation and use of critical crops in prehistory. Archaeol Anthropol Sci.

6. Nesbitt M (2005) Grains. In: Prance G, Nesbitt M (Eds.), The cultural history of plants. Routledge Press, New York, USA.

7. McSorley RM, Ozores-Hampton PA, Stansly, Conner M (1999) Nematode management, soil fertility, and yield in organic vegetable production. Nematropica 29(2): 205-213.

8. Lakshmi PM, Jaison S, Muthukumar T, Muthukumar M (2013) Assessment of metal accumulation capacity of Brachiaria ramosa collected from cement waste dumping area for the remediation of metal contaminated soil. Ecological Engineering 60: 96-98.

9. Coastal Zone Resources Division (1978) Handbook for terrestrial wild life habitat development on dredged material. US Army Eng, Waterways Exp Sta Tech Rep D-78-37, p. 391.

10. Mallikarjuna Hosapalya (2016) Korale's growing popularity. Deccan Herald News Paper.
Your next submission with Juniper Publishers will reach you the below assets

- Quality Editorial service

- Swift Peer Review

- Reprints availability

- E-prints Service

- Manuscript Podcast for convenient understanding

- Global attainment for your research

- Manuscript accessibility in different formats

( Pdf, E-pub, Full Text, Audio)

- Unceasing customer service

Track the below URL for one-step submission https://juniperpublishers.com/online-submission.php 